Landslides (2020) 17:2005-2011 DOI 10.1007/s10346-020-01487-3 Received: 10 July 2020 Accepted: 10 July 2020 Published online: 26 August 2020 (c) Springer-Verlag GmbH Germany part of Springer Nature 2020

\section{Kyoji Sassa \\ The Fifth World Landslide Forum (WLF5) on 2-6 November 2021, Kyoto, Japan}

The Fifth World Landslide Forum (WLF5) was originally planned to be organized on 2-6 November 2020. However, due to the COVID-19 pandemic, the Organizing Committee of $\mathrm{WLF}_{5}$ decided to postpone the WLF5 for 1 year to 2-6 November 2021 at the same venue (Kyoto International Conference Center) in Kyoto, Japan. Meanwhile, two thematic issues of Landslides titled "Sendai Landslide Partnerships 2015-2025" and six volumes of full color books titled "Understanding and Reducing Landslide Disaster Risk," which are the inaugural volumes of new ICL book series ICL contribution to landslide disaster risk reduction (ISSN 2662-1894 (print version) and ISSN2662-1908 (electronic version)), will be published in October or November 2020, as initially scheduled. The 2020 ICL-IPL online virtual Conference will be organized on 2-6 November 2020 (original date of $\mathrm{WLF}_{5}$ ). The Kyoto Landslide Commitment 2020 (KLC2020) will be established at the launching session on 5 November 2020 (World Tsunami Awareness Day) as a part of the virtual conference. Due to its postponement, activities of WLF5 are expanded from 2020 to 2021 and new activities have been added for the forum in 2021 while the organization structure is kept the same. The updated information is presented in this article.

Date: 2-6 November 2021

Venue: Kyoto International Conference Center, Kyoto, Japan Organizers:

International Consortium on Landslides (ICL)

Global Promotion Committee of International Programme on Landslides (IPL-GPC), including United Nations Educational, Scientific and Cultural Organization (UNESCO); World Meteorological Organization (WMO); Food and Agriculture Organization (FAO); United Nations Office for Disaster Risk Reduction (UNDRR); United Nations University (UNU); International Science Council (ISC); World Federation of Engineering Organizations (WFEO); International Union of Geological Sciences (IUGS); International Union of Geodesy and Geophysics (IUGG). Kyoto University (KU); Japan Landslide Society (JLS); Japanese Geotechnical Society (JGS); Japan Society for Natural Disaster Science (JSNDS); Japan Association for Slope Disaster Management (JASDiM).

\section{Cosponsors:}

Cabinet Office (Disaster Management Bureau) of Japan; Ministry of Foreign Affairs of Japan (MOFA); Ministry of Education, Culture, Sports, Science and Technology-Japan (MEXT); Ministry of Land Infrastructure, Transport and Tourism (MLIT); Ministry of Agriculture, Forestry and Fisheries (MAFF); Science Council of Japan (SCJ); Japan International Cooperation Agency (JICA); Japan Society of Civil Engineers (JSCE); Japanese Society of Irrigation, Drainage and Rural Engineering (JSIDRE); Japan Society of Erosion Control Engineering; Japan Society of Engineering Geology.

\author{
Supporting Organizations with Finance: \\ Tokyo Geographical Society; International Union of Geological \\ Sciences (IUGS); Association for Disaster Prevention Research, \\ Kyoto, Japan.
}

\section{Aim}

World Landslide Forum has been organized every 3 years after the first forum in Tokyo, Japan, in 2008. It is a common platform for scientists, engineers, practitioners, and policymakers who are involved in landslide disaster risk reduction to present their latest progress. The Sendai Landslide Partnerships 2015-2025 for Global Promotion of Understanding and Reducing Landslide Disaster Risk was adopted on 16 March 2015 as a voluntary commitment to the United Nations World Conference on Disaster Risk Reduction, held in Sendai, Japan, in 2015. It is a supporting tool for the implementation of the Sendai Framework for Disaster Risk Reduction 2015-2030. In order to implement further the Sendai Landslide Partnerships 2015-2025 and pursue and enhance efforts to 2030 and beyond, the Kyoto 2020 Commitment for global promotion of understanding and reducing landslide disaster risk (KLC2020)-A Commitment to the Sendai Landslide Partnerships 2015-2025, the Sendai Framework for Disaster Risk Reduction 20152030, the 2030 Agenda Sustainable Development Goals, the New Urban Agenda, and the Paris Agreement-will be formally launched by all signatory organizations at the online launching session of KLC2020 on 5 November 2020.

The Fifth World Landslide Forum will be the opportunity to achieve a mid-term review of the Sendai Landslide Partnerships 2015-2025 and 1-year review and planning of the further development strategy of KLC2O2O.

\section{Organizing Committee}

\section{Honorary Chairpersons}

Audrey Azoulay, Director-General of UNESCO*; Mami Mizutori, Special Representative of the United Nations Secretary-General for Disaster Risk Reduction*; Petteri Taalas, Secretary-General of WMO*; Qu Dongyu, Director-General of FAO *; David Malone, Under-Secretary General of the Unitred Nations and Rector of UNU; Daya Reddy, President of ISC; Gong Ke, President of WFEO; Qiuming Cheng, President of IUGS; Kathryn Whaler, President of IUGG; Qunli Han, Executive Director of Integrated Research on Disaster Risk (IRDR); Walter Ammann, President and CEO of Global Risk Forum GRF Davos, Switzerland; Juichi Yamagiwa, President of Kyoto University, Japan; Angelo Borrelli, Head of the National Civil Protection Department, Italian Presidency of the Council of Ministers, Italy; Darko But, Director General of the Administration for Civil Protection and Disaster Relief of the Republic of Slovenia, Slovenia; Akifumi Nakao, Director, 
International Cooperation Division, Disaster Management Bureau, Cabinet Office, Japan; Kazuyuki Imai, Director General of Sabo Department, Ministry of Land Infrastructure, Transport and Tourism, Japan*; Chungsik Yoo, President of the International Geosynthetics Society; Rafig Azzam, President of the International Association for Engineering Geology and the Environment $\left(^{*}\right.$ : to be confirmed).

\section{Chairpersons}

Kyoji Sassa (Professor Emeritus, Kyoto University, Secretary General of ICL), Peter Bobrowsky (Geological Survey of Canada, President of ICL), Kaoru Takara (Kyoto University, Japan, Executive Director of ICL).

\section{Organizing Committee Members}

Željko Arbanas (University of Rijeka, Croatia), Snježana Mihalić Arbanas (University of Zagreb, Croatia), Nicola Casagli (University of Firenze, Italy), Fausto Guzzetti (Department of Civil Protection, Italy), Matjaž Mikoš (University of Ljubljana, Slovenia), Paola Reichenbach (Research Institute for Geo-Hydrological Protection, National Research Council, Italy), Shinji Sassa (Port and Airport Research Institute, Japan), Alexander Strom (Geodynamics Research Center LLC, Russia), Binod Tiwari (California State University, Fullerton, USA), Veronica Tofani (University of Firenze, Italy), Vít Vilímek (Charles University in Prague, Czech Republic), Fawu Wang (Tongji University, China).

\section{Chairpersons of Local Organizing Committee}

Kaoru Takara (Kyoto University), Daisuke Higaki (Japan Landslide Society), Ikuo Towhata (Japanese Geotechnical Society).

\section{Secretary Generals}

Ryosuke Uzuoka (Disaster Prevention Research Institute, Kyoto University), Kazuo Konagai (International Consortium on Landslides), Khang Dang (International Consortium on Landslides).

\section{Kyoto International Conference Center}

The Kyoto International Conference Center (KICC) in Kyoto, Japan, is selected as the venue of the Fifth World Landslide Forum (Fig. 1). It was constructed in May 1966 by the decision of the Cabinet of Japan as the national conference center to host major international conferences in Kyoto, Japan. The Kyoto Protocol was adopted in KICC in the Third Session of the Conference of the Parties $\left(\mathrm{COP}_{3}\right)$ to the United Nations Framework Convention on Climate Change in December 1997; the third World Water Forum was in March 2003.

\section{Forum Publication}

1 Journal thematic issues "Sendai Landslide Partnerships 20152025" will be published in October and in November 2020. The author of the accepted paper will be invited as an invited lecturer of $\mathrm{WLF}_{5}$ for 20-min oral presentation.
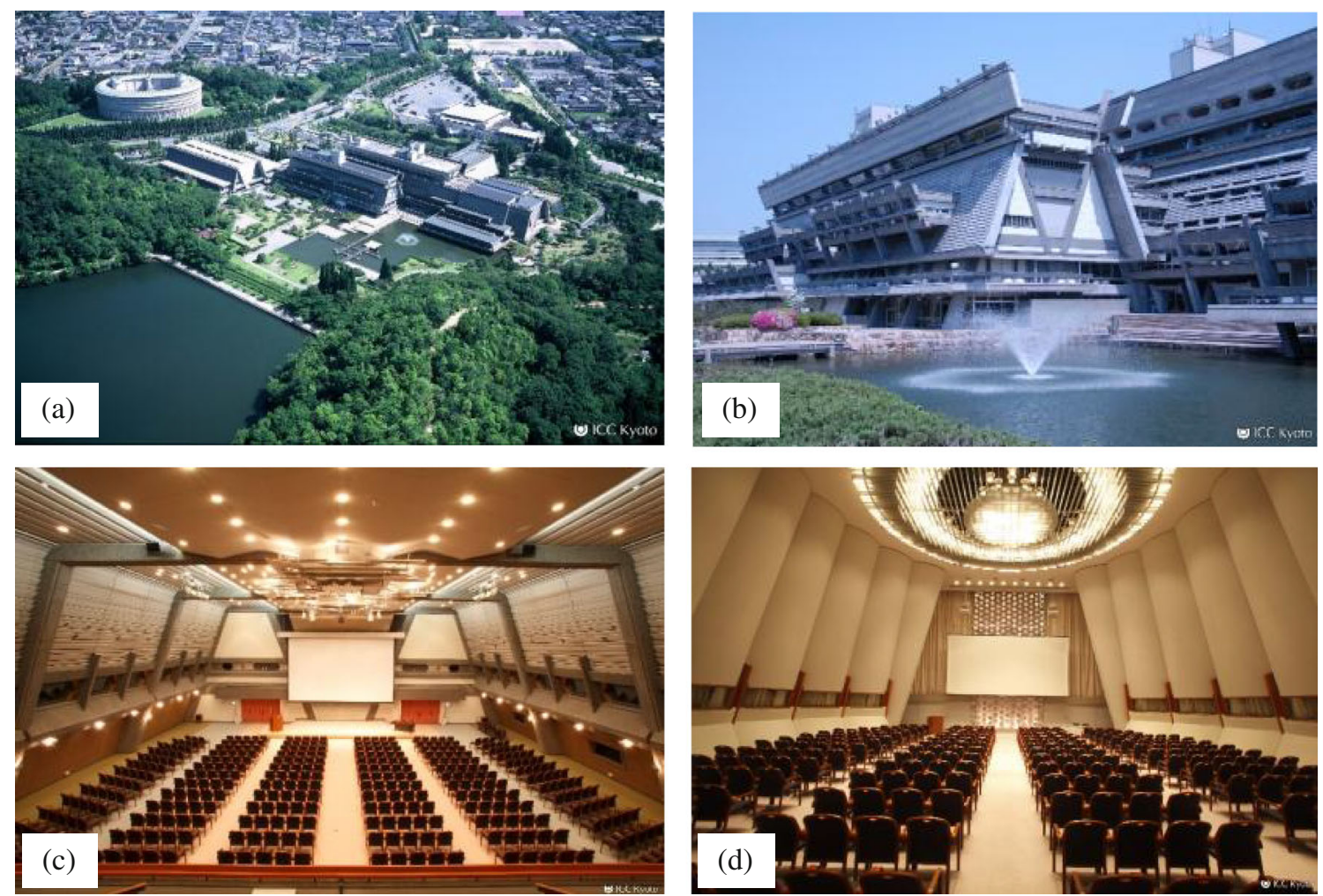

Fig. 1 Photos of the Kyoto International Conference Center (KICC). (a) and (b): Overview of the KICC, (c): Room A for Plenary Session on 3 November 2021 , (d) Room D for World Tsunami Awareness Day Event on 5 November 2021 and Closing Session on 6 November 2021. 
2 Journal thematic issue "Kyoto Landslide Commitment 2020" will be published in November 2021. The author of the accepted paper will be invited as an invited lecturer of WLF5 for 20-min oral presentation.

3 Six volumes of full-color books titled "Understanding and Reducing Landslide Disaster Risk," which are the inaugural volumes of new ICL book series "ICL contribution to landslide disaster risk reduction (ISSN 2662-1894 (print version) and ISSN2662-1908 (electronic version)) will be published in December 2020.

\begin{tabular}{|llc}
\hline Volume 1 & $\begin{array}{l}\text { Sendai Landslide Partnerships and Kyoto } \\
\text { Landslide Commitment }\end{array}$ & 579 pages \\
\hline Volume 2 & From Mapping to Hazard and Risk Zonation & 418 pages \\
\hline Volume 3 & Monitoring and Early Warning & 322 pages \\
\hline Volume 4 & Testing, Modeling and Risk Assessment & 456 pages \\
\hline Volume 5 & $\begin{array}{l}\text { Catastrophic Landslides and Frontiers of Landslide } \\
\text { Science }\end{array}$ & 374 pages \\
\hline Volume 6 & $\begin{array}{l}\text { Specific Topics in Landslide Science and } \\
\text { Applications }\end{array}$ & 386 pages \\
\hline
\end{tabular}
ceedings is one-page title/author/office and abstract $+5-9$ pages of 2 PPT slides/page. The deadline for submission of the session proceedings to the WLF5 secretariat is 31 July 2020. All session proceedings to the $\mathrm{WLF}_{5}$ secretariat will be compiled as $\mathrm{WLF}_{5}$ electronic proceedings with ISBN number. It will be published in November 2020.

5 One-Page Abstract volume: WLF5 in 2021 will invite speakers for a one-page text-based abstract (with no figures or photos). The deadline for the session proposal is 28 February 2021 and the submission deadline of the onepage abstract is 30 June 2021. Acceptance will be informed by 31 July 2021 .

WLF5 abstract volume will be published. ISBN will be assigned to this volume. Authors can choose among (1) 10-min oral presentation, (2) no talk, or (3) no attendance.

6. Electronic posters: Each E-Poster is Ao size $(841 \times 1189 \mathrm{~mm})$ in PPT format.

Template < http://wlf5.iplhq.org/wp-content/uploads/2019/10/ E-Poster.pptx $>$. All accepted electronic posters will be numbered and uploaded on the web for downloading by registered participants. Each poster is cited by its number of the WLF5 electronic posters. The submission deadline for Electronic posters is 30 June 2021. Acceptance will be informed by 31 July 2021. Authors can choose among (1) 3-min oral presentation, (2) no talk, or (3) non-attendance.

Schedule, Programmes and Themes

The schedule of publication, registration and KLC2020

\begin{tabular}{|c|c|c|c|c|c|c|c|c|}
\hline Month & $9-10$ & 11-12 & $1-2$ & 3 & $4-6$ & 7 & 8-10 & WLF5 \\
\hline Year & \multicolumn{2}{|c|}{2020} & \multicolumn{5}{|c|}{2021} & 3-6 November 2021 \\
\hline $\begin{array}{l}\text { Journal } \\
\text { thematic Issue }\end{array}$ & \multicolumn{4}{|c|}{ Submission/Review } & \multicolumn{3}{|c|}{ Review/Publication } & $\begin{array}{l}\text { Thematic issue } \\
\text { "KLC2020" } \\
\text { Vol.18-10 and } 11\end{array}$ \\
\hline One-page abstract & \multicolumn{3}{|c|}{$\begin{array}{c}\text { Session Proposal } \\
\text { (by } 28 \text { February 2021) }\end{array}$} & \multicolumn{2}{|c|}{$\begin{array}{l}\text { Abstract submission } \\
\text { (by } 30 \text { June 2021) }\end{array}$} & $\begin{array}{l}\text { Notice of } \\
\text { Acceptance } \\
\text { (by } 31 \text { July) }\end{array}$ & $\begin{array}{l}\text { Programme } \\
\text { making }\end{array}$ & $\begin{array}{l}\text { Choice of } 10 \text {-minute oral } \\
\text { presentation, no talk, or } \\
\text { no attendance }\end{array}$ \\
\hline $\begin{array}{l}\text { Electronic Posters } \\
\text { One A0 page poster }\end{array}$ & \multicolumn{5}{|c|}{$\begin{array}{l}\text { Submission of posters } \\
\text { (by } 30 \text { June 2021) }\end{array}$} & $\begin{array}{l}\text { Notice of } \\
\text { Acceptance } \\
\text { (by } 31 \text { July) }\end{array}$ & $\begin{array}{l}\text { Programme } \\
\text { making }\end{array}$ & $\begin{array}{l}\text { Choice of 3-minute talk, } \\
\text { no talk, or no attendence }\end{array}$ \\
\hline Panel exhibition & \multicolumn{7}{|c|}{$\begin{array}{c}1200 \mathrm{~mm} \times 2100 \mathrm{~mm} \text { panel exhibition (in the center of Exhibition Room B-1) } \\
\text { Max } 20 \text { exhibition panels (JPY150,000 including } 2 \text { non-speaker registration tickets ) } \\
\text { Call is closed when the application number will reach } 20\end{array}$} & 3-6 November 2021 \\
\hline \multirow{2}{*}{ Registration } & \multicolumn{4}{|c|}{ Early registration (by 31 March 2021) } & \multicolumn{2}{|c|}{$\begin{array}{l}\text { Normal registration } \\
\text { (by } 31 \text { July 2021) }\end{array}$} & \multicolumn{2}{|c|}{ Late registration } \\
\hline & \multicolumn{8}{|c|}{ Registration fee for those who paid the publication fee for Books and E-posters in June-July 2020 will be reduced } \\
\hline $\begin{array}{l}\text { Kyoto Landslide } \\
\text { Commitment } 2020 \\
(\text { KLC2020) }\end{array}$ & \multicolumn{4}{|c|}{$\begin{array}{l}\text { By } 5 \text { September } 2020 \text { : Registration to } \\
\text { participate in the launching session. } \\
5 \text { November } 2020 \text { : Launching session of } \\
\text { KLC2020 }\end{array}$} & \multicolumn{3}{|c|}{$\begin{array}{l}\text { Report of the launching session in Vol.18-1 } \\
\text { with group photo of participants. } \\
\text { Introduction of KLC2020 partners in Vol.18-2 } \\
\text { and subsequent issues. }\end{array}$} & $\begin{array}{l}\text { High-level Panel } \\
\text { Discussion for KLC2020 } \\
\text { Way Forward. } \\
\text { The Second Session of } \\
\text { KLC2020 signatories. }\end{array}$ \\
\hline
\end{tabular}




\section{Programme of the Forum}

\begin{tabular}{|c|c|c|}
\hline Date & Time & Activities \\
\hline \multirow[t]{4}{*}{2 Nov. 2021} & 9:00-18:00 & Forum Registration \\
\hline & 9:00-16:00 & $\begin{array}{l}20^{\text {th }} \mathrm{BOR} / \mathrm{ICL} \text { and } 16^{\text {th }} \mathrm{GPC} / \mathrm{IPL} \\
\text { meeting }\end{array}$ \\
\hline & 16:00-17:00 & $20^{\text {th }}$ Anniversary ceremony of ICL \\
\hline & $17: 30-19: 30$ & $20^{\text {th }}$ Anniversary dinner \\
\hline \multirow[t]{6}{*}{3 Nov. 2021} & 9:00 - 9:50 & $\begin{array}{l}\text { Opening addresses: ICL, ICL } \\
\text { supporting organizations and host } \\
\text { organization }\end{array}$ \\
\hline & $10: 00-12: 00$ & $\begin{array}{l}\text { High-level Panel Discussion or } \\
\text { KLC2020 review and way forward } \\
\text { Panelists: Representatives of } \\
\text { KLC2020 signatories }\end{array}$ \\
\hline & 12:00-13:30 & Lunch \\
\hline & 13:30-15:30 & $\begin{array}{l}\text { Forum lectures } \\
\text { Lecturer from UNDRR: Promotion of } \\
\text { the Sendai Framework for Disaster } \\
\text { Risk Reduction } \\
\text { Fausto Guzzetti (Italy): On the } \\
\text { prediction of landslides and their } \\
\text { consequence } \\
\text { Charles NG (Hong Kong, China): } \\
\text { Interaction mechanisms between } \\
\text { debris flow and multiple barriers }\end{array}$ \\
\hline & $15: 45-17: 00$ & $\begin{array}{l}\text { Recognition and Awards } \\
\text { Ceremony } \\
\text { World Centres of Excellence on } \\
\text { Landslide Risk Reduction (WCOEs) } \\
2020-2023 \\
\text { Bestow the Varnes Medal, IPL } \\
\text { Awards for 2017-2021 }\end{array}$ \\
\hline & 18:30-21:00 & Welcome Reception \\
\hline \multirow[t]{3}{*}{4 Nov. 2021} & 9:30-12:00 & $\begin{array}{l}\text { ICL-KLC2020 Intergovernmental } \\
\text { round table discussion }\end{array}$ \\
\hline & $9: 00-17: 00$ & Parallel Sessions \\
\hline & $9: 00-18: 00$ & Exhibition in Booths and Panels \\
\hline \multirow[t]{2}{*}{5 Nov. 2021} & 9:00-17:00 & $\begin{array}{l}\text { Special Event of World Tsunami } \\
\text { Awareness Day } \\
\text { Special Lectures and Panel Discussion } \\
\text { on Landslide-induced Tsunamis }\end{array}$ \\
\hline & $9: 00-17: 00$ & Parallel Session \\
\hline \multirow[t]{3}{*}{6 Nov. 2021} & $9: 00-12: 00$ & Parallel Sessions \\
\hline & $12: 00-13: 30$ & Lunch \\
\hline & $13: 30-15: 30$ & Forum Lectures \\
\hline
\end{tabular}

Michel Jaboyedoff

(Switzerland): Improving the rockfall failure hazard assessment. Brian Collins (U.S.A): Progress and lessons learned from responses to catastrophic landslides

15:30-17:00 Closing Ceremony

$>$ Speech by the new President of ICL (2021.1.1 - 2023.12.31)

$>$ Introduction of new ICL officers by New ICL President $>$ Certificates to new ICL members (2017-2021) by ICL President $\triangleright$ Acknowledgement to WLF5 supporting organizations with financial support and sponsors by ICL President $\triangleright$ Welcome to 6th WLF (WLF6 Forum Chair)

The parallel sessions of WLF5 will be organized with Theme 1 to Theme 8 on 4-6 November 2021. All accepted papers for Journal thematic issues, full-color books, electronic proceedings, and onepage abstract volumes will be presented in Theme 1-Theme 8 as follows.

Theme 1: Sendai Landslide Partnerships and Kyoto Landslide Commitment

First Coordinator: Kyoji Sassa (ICL Headquarters)

Theme 2: Hazard and vulnerability mapping and zonation

First Coordinator: Fausto Guzzetti (Department of Civil Protection, Italy)

Theme 3: Monitoring and early warning

First Coordinator: Nicola Casagli (University of Firenze, Italy)

Theme 4: Testing, modeling and risk assessment

First Coordinator: Binod Tiwari (California State University, Fullerton, USA)

Theme 5: Education and Capacity Development for Risk Management and Risk Governance

First Coordinator: Matjaž Mikoš (University of Ljubljana, Slovenia)

Theme 6: Catastrophic landslides: causes and consequences

First Coordinator: Vit Vilimek (Charles University in Prague, Czech Republic)

Theme 7: Frontiers of landslide science and innovative practices First Coordinator: Peter Bobrowsky (Geological Survey of Canada)

Theme 8: Specific topics in landslide science and applications

First Coordinator: Željko Arbanas (University of Rijeka, Croatia) 


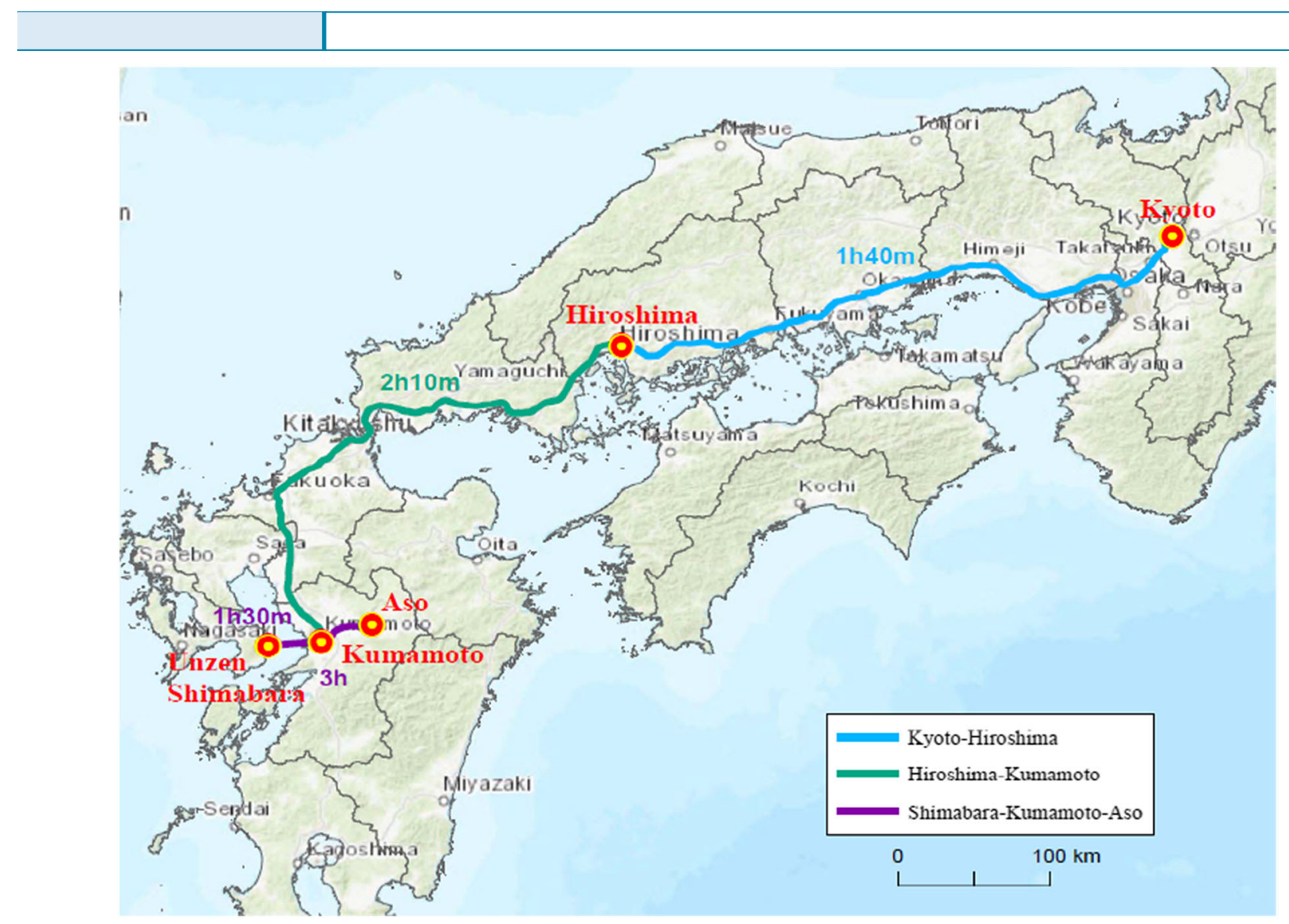

Fig. 2 The route map of field trip on 7-9 November 2021

Post-Conference Field Trip (Max 30 Persons)

Field trip to urban landslides in Hiroshima, landslide-induced tsunami in Unzen volcano, and earthquake-induced landslides in Kumamoto will be organized on 7-9 November 2021 (Fig. 2).

\section{1st day in Hiroshima (7th Nov. 2021)}

Start from Kyoto by Shinkansen: Urban landslide disasters triggered by local extreme rainfalls. World Cultural Heritage "Itsukushima Shrine" and "Hiroshima Peace Memorial Park" (stay in Hiroshima).

\section{2nd day in Unzen (8 Nov. 2021)}

From Hiroshima to Kumamoto by Shinkansen and to UnzenShimabara by bus and ferry: 1792 Unzen-Mayuyama megaslide by an earthquake and caused a big tsunami disaster. Visit to Unzen Volcanic Area Global Geopark, Unzen Disaster Memorial Hall (stay in Unzen Hot Spring).

\section{3rd day (9 Nov. 2021)}

From Unzen Hot Spring to the Shimabara port by bus and ferry to Kumamoto (observation from the ferry to Unzen volcano and megaslide): Visit to the landslides induced by the 2016 Kumamoto earthquake in the Aso caldera area. Leave from Kumamoto Station/Airport to Osaka by railway, or from Kumamoto airport to Osaka, Tokyo, or others.

\section{Registration}

Registration will be accepted through the WLF5 WEB registration page $<$ http://wlf5.iplhq.org/registration $>$ or directly to the registration page by Japan Travel Bureau <https://amarys-jtb.jp/ wlf5/?\&g=1>.

The registration fee for all categories of participation is shown below, and all updated information of $\mathrm{WLF}_{5}$ is printed in the WLF5 outline and the WLF5 information board of the back matters of each issue of Journal Landslides. 


\section{Registration Timeline and Fee of WLF5}

Forum Registration Website: http://wlf5.iplhq.org/registration/

\begin{tabular}{|c|c|c|c|}
\hline Speaker Registration & $\begin{array}{l}\text { Early } \\
\text { (01 Oct. } 2019 \text { to } 31 \text { Mar. 2021) }\end{array}$ & $\begin{array}{l}\text { Normal } \\
\text { (01 Apr. to 31 Jul. 2021) }\end{array}$ & $\begin{array}{l}\text { Late and On-Site } \\
\text { (After 01 Aug. 2021) }\end{array}$ \\
\hline Regular & $66,000 \mathrm{JPY}$ & 71,000 JPY & 76,000 JPY \\
\hline $\begin{array}{l}\text { ICL Board, Deputy Board member, } \\
\text { ICL Supporter (up to } 2 \text { persons) }\end{array}$ & $46,000 \mathrm{JPY}$ & $51,000 \mathrm{JPY}$ & 76,000 JPY \\
\hline ICL Associates & $56,000 \mathrm{JPY}$ & 61,000 JPY & 76,000 JPY \\
\hline One-page abstract (New) & \multicolumn{2}{|c|}{$36,000 \mathrm{JPY}$} & $x$ \\
\hline E-Posters (New) & \multicolumn{2}{|c|}{$36,000 \mathrm{JPY}$} & $x$ \\
\hline Students & \multicolumn{3}{|c|}{$26,000 \mathrm{JPY}$} \\
\hline \multicolumn{4}{|c|}{$\begin{array}{l}\text { Registration fee includes Vol.1 of Full color books (except authors of one-page abstract and E-posters), E-Proceedings, } \\
\text { E-posters and Abstract volume. }\end{array}$} \\
\hline \multicolumn{4}{|c|}{ Registration fee for non-speaker/non-poster publication } \\
\hline Regular & \multicolumn{3}{|c|}{ 26,000 JPY (incl. E-proceedings, E-posters, Abstract volume) } \\
\hline Spouses & \multicolumn{3}{|c|}{$16,000 \mathrm{JPY}$ (including reception) } \\
\hline World Tsunami Awareness Day & \multicolumn{3}{|c|}{ 20,000 JPY (including lunch) } \\
\hline \multicolumn{4}{|c|}{ Options } \\
\hline Conference Reception & \multicolumn{3}{|c|}{$10,000 \mathrm{JPY}$} \\
\hline Lunch $(3,5,6$ November 2021) & \multicolumn{3}{|c|}{ 3,000 JPY for 3 days (no single lunch sale) } \\
\hline Full color books (5 E-books) & \multicolumn{3}{|c|}{ 30,000 JPY (No.2, No.3, No.4, No.5, No.6; no single volume sale) } \\
\hline
\end{tabular}

\section{Call for WLF5 Supporting Organizations with Financial Support}

WLF5 supporting organizations with Financial support (more than 3,000 USD or 300,000 JPY) are called for. Appreciations to the supporting organizations will be published in Bulletins, WLF5 pages in each issue of the Journal "Landslides", all volumes of the WLF5 full color books, and its E-Proceedings. The representative of each organization is invited to attend all sessions, the reception, and lunches throughout the WLF5. The ICL President will present his sincere appreciation for their supports at the closing ceremony.

Supporting Organizations who provided financial support as of 4 July 2020: Tokyo Geographical Society, International Union of Geological Sciences (IUGS), Association for Disaster Prevention Research, Kyoto, Japan

\section{Call for Panel Exhibition (new)}

$1200 \mathrm{~mm} \times 2100 \mathrm{~mm}$ panel exhibition (in the center of Exhibition Room B-1) is called.

Max 20 exhibition panel facilities are available. Registration fee is JPY150,000. 2 non-speaker registration tickets are offered to an exhibitor. As of 4 July 2020, a Japanese local government applied for a panel exhibition.

\section{Sponsors (Landslide related companies)}

Type A (JPY 500,000): Marui \& Co., Ltd., NIPPON KOEI Co., Ltd., OSASI Technos Inc., GODAI Corporation, Japan Conservation Engineers \& Co., Ltd., OYO Corporation, Kokusai-Kogyo Co., Ltd., GEOBRUGG, Ellegi srl (LiSALab), Chuo Kaihatsu Corporation, IDS GeoRadar s.r.l., Meter Group Inc., Asia Air Survey Co. Ltd., Type A-1 (JPY 400, 000): We are now calling for one sponsor. One booth space $(4 \mathrm{~m} \mathrm{x} 3 \mathrm{~m})$ and 3 non-speaker tickets are offered.

Type B (JPY 300, 000): Kiso-Jiban Consultants Co., Ltd., Okuyama Boring Co., Ltd., Kawasaki Geological Engineering Co., Ltd., Water\&Geo-tech Engineers, Nissaku.

Calling for further 3 sponsors: One poster $(1200 \times 2100 \mathrm{~mm}), 4$ non-speaker tickets and Sponsor banners (logo, name of company and link to its web) in WLF5 web are offered. 
Call for supports to the Sendai Landslide Partnerships 2015-2025 and KLC2020, and contribution to new publication for WLF5

The International Consortium on Landslides (ICL) calls for support to two initiatives of the Sendai Landslide Partnerships 20152025 (Sassa 2015; Wahlström 2015; Mizutori 2020) and KLC2020 which is the development of Sendai Landslide partnerships until 2030 and beyond (Sassa, 2019a, b, c and 2020).

The Fifth World Landslide Forum is the opportunity of the review of the Sendai Landslide Partnerships 2015-2025 as its midterm, the review of the initial 1 year of $\mathrm{KLC}_{2020}$, and to plan a path forward. For the success of $\mathrm{WLF}_{5}$, the organizing committee is calling for WLF5 supporting organization with financial support, panel exhibition, and one Sponsor A and three Sponsor B.

WLF5 has been postponed for 1 year from the originally planned date. Papers of 6 volumes of full-color books and two thematic issues "Sendai Landslide Partnerships 2015-2025" will be published in 2020. The WLF5 organizing committee is calling for another thematic issue "Kyoto Landslide Commitment 2020 "; authors of accepted papers will be invited lecturers in the forum. WLF5 is also calling for one-page abstract speakers and electronic poster presenters for WLF 5 in 2021. Session proposals for one-page abstract papers will be accepted by 28 February 2021. The submission deadline of one-page abstract and e-posters is 30 June 2021.

\section{WLF5 Secretariat}

Other information is available from WLF5 WEB or Email. WEB: https://wlf5.iplhq.org/

Email: WLF5 secretariat wlf5-sec@iclhq.org

References

Mizutori M (2020) Foreword for the Journal of the International Consortium on Landslides. Landslides 17(4):753

Sassa K (2015) ISDR-ICL Sendai Partnerships 2015-2025 for global promotion of understanding and reducing landslide disaster risk. Landslides 12(4):631-640

Sassa K (2019a) The Fifth World Landslide Forum and the final draft of the Kyoto 2020 Commitment. Landslides 16(2):201-211

Sassa K (2019b) Journal Landslides, the International Consortium on Landslides, and the Kyoto Landslide Commitment 2020. Landslides 16(9):1623-1628

Sassa K (2019c) The Kyoto Landslide Commitment 2020: first signatories. Landslides 16(11):2053-2057

Sassa K (2020) Launching session of the Kyoto Landslide Commitment 2020. Landslides 17(8):1743-1744

Wahlström M (2015) Preface. Landslides 12(4):629

K. Sassa $(\varangle)$

International Consortium on Landslides (ICL),

Kyoto, Japan

Email: secretariat@iclhq.org 